\title{
Assistance Of Students In The Framework Of Global Hinness Through Community Games And Traditional Sports
}

\author{
Moch. Purnomo ${ }^{1}$, Dian Ayu Larasati ${ }^{2}$, Corry Liana ${ }^{3}$ \\ \{mochamadpurnomo@unesa.ac.id ${ }^{1}$, dianlarasati@unesa.ac.id ${ }^{2}$,corryliana@unesa.ac.id ${ }^{3}$ \} \\ Universitas Negeri Surabaya, Indonesia ${ }^{1,2,3}$
}

\begin{abstract}
In the era children who spend most of their time in coffee shops and internet cafes, just to play online games. 2020 is a tough year, because the world is being hit by the Covid-19 pandemic, a healthy body is the main point to be able to carry out movement activities properly, a healthy body and good movement are obtained through one suitable activity, namely sports activities. One model of learning gross motoric movements through folk games and traditional sports because it can be conveyed to students more easily, fun, according to the stages of development, characteristics, and age. Implementation of character value mentoring through folk games and traditional sports, through direct practice in games, giving flascards of character and module values, the teacher serving as a facilitator, the result was that $79 \%$ of students showed increased understanding of folk games and the characters in them.
\end{abstract}

Keywords: Mentoring, character values, folk games, traditional sports.

\section{Introduction}

Character education has become a concern of the world of education in Indonesia in order to prepare a quality generation, not only for the benefit of individual citizens, but also for citizens of society as a whole. Character education can be interpreted as an effort made deliberately from all dimensions of school life to help build character optimally [1].

It is hoped that the development of character values will always exist in every educational context, be it formal, informal or non-formal education. The world of education is expected to be a driving force to facilitate character development, so that members of society have an awareness of a harmonious and democratic nation and state life while still paying attention to the norms in society that have become a collective agreement. Character development and character education are imperative because education not only makes students smart, but also has to have good manners and manners so that their existence as a member of society has good meaning for themselves.

Character education and culture have a very strong relationship. Character education cannot be separated from culture. Without the educational process it is impossible for that culture to continue and develop. The educational process is nothing more than a process of cultural transmission. In an anthropological perspective, education is a transformation of a socio-cultural system from one generation to another in a society. [2] explained that "Education is a cultural process". In other words, education and culture have an inseparable relationship. When talking about education, culture also participates in it. There is no culture without education and thus 
educational praxis is always within the sphere of culture. The noble cultural values possessed by community groups in Indonesia already belong to the nation as an invaluable potential for the development and progress of the Indonesian nation. Indonesian society is a pluralistic society in terms of culture, religion, and language which has values. Cultural noble values are often referred to as local wisdom. [3], local wisdom is the human intelligence possessed by certain ethnic groups obtained through community experience. This means that local wisdom is the result of certain communities through their experiences and is not necessarily experienced by other communities. These values will be very strongly attached to certain societies and these values have been through a long period of time, as long as the existence of that society.

With advanced technology, children spend more of their time playing games either in internet cafes using personal computers or by using gadgets in coffee shops [4]. This raises several problems, where these habits can unconsciously make the child have a closed personality and are insensitive to the surrounding environment so that the child is an individualist. Such traits will tend to form a character that is not good and will have an impact on the family environment and educational environment, as well as interfere with children's motor development.

The 2015-2019 National Medium-Term Development Plan (RPJMN) has set nine priority agendas known as the Nawacita Program, in which the development of National education and culture is directed towards realizing the Nawacita namely improving the quality of Indonesian human life, increasing productivity and competitiveness, revolutionizing the character of the nation. , as well as reinforcing diversity and strengthening Indonesia's social restoration. To achieve that, the development and strengthening of character through mentoring activities is a comprehensive effort carried out through the development of an educational ecosystem, both within the family, school and community [5].

The development and strengthening of character through cultural advancement activities are one of the important elements in the progress of a country in living life in the era of globalization [3]. Furthermore, in Law number 5 of 2017, the objects of cultural advancement include folk games and traditional sports [4]. To improve the quality of life, competitiveness, development of national character, as well as to see the development of skills and competencies needed in the 21st century, stimulation of experience and enrichment of various motor skills at school age is needed through cultivating folk games and recreational sports. Individuals who in their childhood have various experiences of basic movement patterns and various activities, will find it easier to carry out various motor skills. The experience of motor skills of children in the past will be the basis for learning skills.

\section{Methods}

The stages of the activities implemented in this mentoring activity are presented in the following Figure 1: 


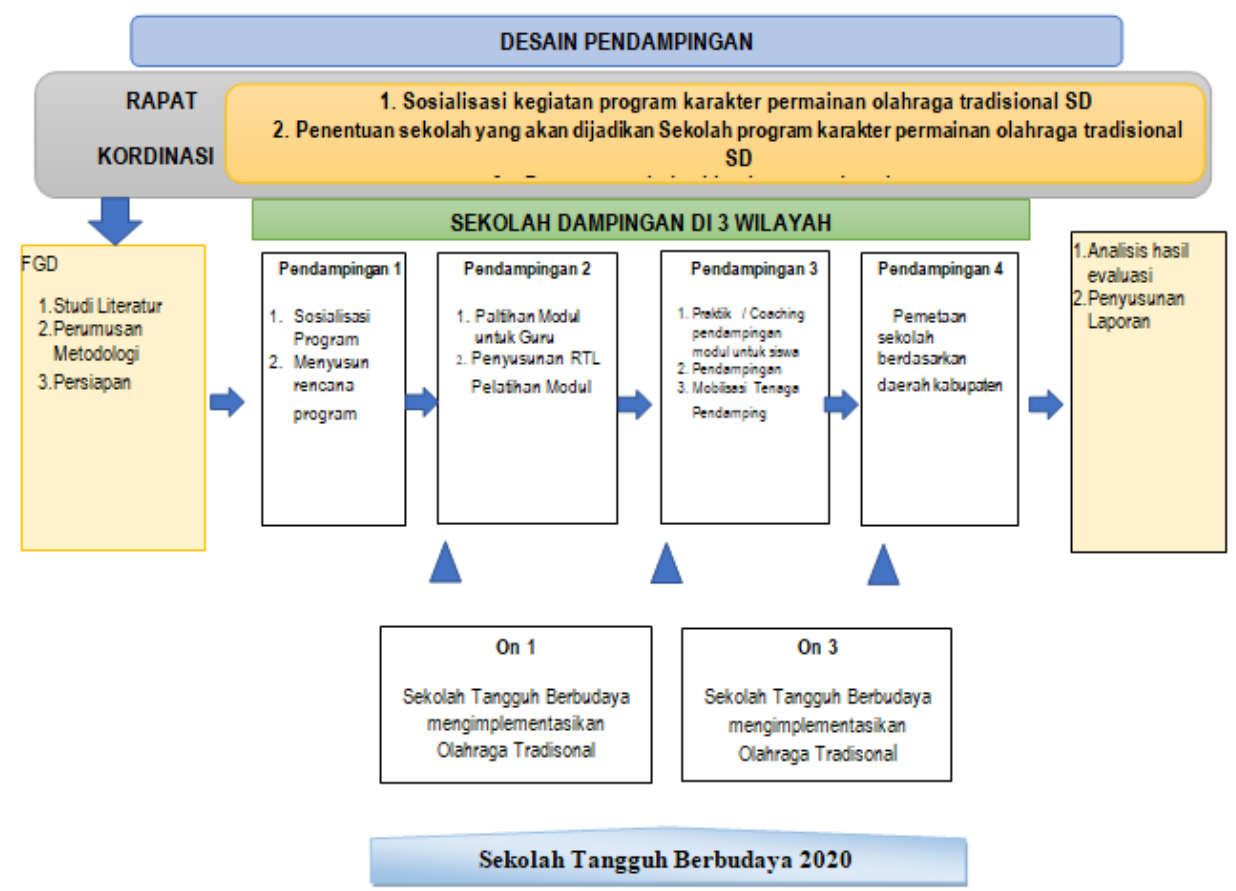

Fig. 1. Activities implemented

The first activity begins with the Socialization of Character Values Assistance through Folk Games and Traditional Sports in Schools. For schools that have been designated as partner schools, they are expected to be able to carry out socialization to stakeholders (parents of students, school committees, and other related institutions or communities). Socialization is carried out through zoom, due to adjusting conditions during the Covid 19 pandemic. The purpose of this socialization is to provide information, explanations, and expectations about matters related to Character Values Assistance activities through Folk Games and Traditional Sports in Schools. Some of the main things that were disseminated included: (a) basics / juridical foundations for the importance of key elements of global diversity (b) school programs to be planned / implemented as assistance for Character Values through Folk Games and Traditional Sports in Schools ( c) targets or indicators of the success of schools as assisted schools in the short, medium and long term, (d) the participation of stakeholders in implementing the development of Character Values through Folk Games and Traditional Sports in Schools (e) other things deemed necessary by the school. The next activity is FGD in the context of equalizing perceptions in implementing the mentoring program, then the Formation of a Team for Assisting Character Values through Folk Games and Traditional Sports at Schools in an effort to facilitate the implementation of assistance for Character Values through Folk Games and Traditional Sports in Schools, then It is hoped that each school will form a development team or task force consisting of PE teachers in the school who are tasked with leading the sector. The aim is to accelerate the preparation of various aspects of character components that will be developed into work plans, and to help evaluate the implementation of character values mentoring programs through traditional sports games in schools. 
It is endeavored that the members of the mentoring team consist of elements from PE teachers and classroom teachers. The team must be given a special time to carry out their duties. The organizational structure of the team will be made clearly so that the duties and responsibilities as well as the authorities will be detailed and clear as well. In principle, the existence of this team is responsible to the principal. The parties involved in this activity are the UNESA Learning Development and Quality Assurance Institute, PE Teachers and School Principals.

\section{The results of study}

\subsection{Assistance in Kediri Regency}

Folk games and traditional sports in Kediri Regency are Patil catfish, Boy-Boyan, Patek, Dampar, Tulup / Dor-Doran, and Gejlek.

Table 1. Pre-test results for students in Kediri Regency

\begin{tabular}{|c|c|c|c|c|}
\hline \multirow{2}{*}{ No } & \multicolumn{2}{|c|}{ Experiment } & \multicolumn{2}{|c|}{ Control } \\
\hline & Student's Name & Score & Student's Name & Score \\
\hline 1 & Student 1 & 32 & Student 1 & 12 \\
\hline 2 & Student 2 & 16 & Student 2 & 20 \\
\hline 3 & Student 3 & 28 & Student 3 & 30 \\
\hline 4 & Student 4 & 40 & Student 4 & 20 \\
\hline 5 & Student 5 & 19 & Student 5 & 30 \\
\hline 6 & Student 6 & 18 & Student 6 & 10 \\
\hline 7 & Student 7 & 8 & Student 7 & 20 \\
\hline 8 & Student 8 & 24 & Student 8 & 10 \\
\hline 9 & Student 9 & 36 & Student 9 & 20 \\
\hline 10 & Student 10 & 20 & Student 10 & 24 \\
\hline 11 & Student 11 & 32 & Student 11 & 17 \\
\hline 12 & Student 12 & 22 & Student 12 & 21 \\
\hline 13 & Student 13 & 32 & Student 13 & 12 \\
\hline 14 & Student 14 & 40 & Student 14 & 5 \\
\hline Sum & & 367 & & 251 \\
\hline Mean & & 26,21 & & 17,92 \\
\hline
\end{tabular}

The results of tests conducted by students in elementary schools showed that the average data obtained from the pre-test students in the two sample classes was 26.21 in the experimental class and 20.71 in the control class. The results of the average data are tested using the t-test hypothesis. The results of the students' pre-t test can be seen the sig value. (2-tailed) $0.01<0.05$, it can be concluded that there is a significant difference between the pre-test experimental class and the control class. 
Table 2. Post-test results for students in Kediri Regency

\begin{tabular}{clclc}
\hline \multirow{2}{*}{ No } & Experiment & \multicolumn{2}{c}{ Control } \\
& Student's Name & Score & Student's Name & Score \\
\hline 1 & Student 1 & 61 & Student 1 & 43 \\
2 & Student 2 & 75 & Student 2 & 45 \\
3 & Student 3 & 70 & Student 3 & 41 \\
4 & Student 4 & 59 & Student 4 & 65 \\
5 & Student 5 & 69 & Student 5 & 52 \\
6 & Student 6 & 67 & Student 6 & 36 \\
7 & Student 7 & 81 & Student 7 & 40 \\
8 & Student 8 & 88 & Student 8 & 33 \\
9 & Student 9 & 72 & Student 9 & 50 \\
10 & Student 10 & 56 & Student 10 & 40 \\
11 & Student 11 & 77 & Student 11 & 34 \\
12 & Student 12 & 61 & Student 12 & 42 \\
13 & Student 13 & 56 & Student 13 & 43 \\
14 & Student 14 & 78 & Student 14 & 34 \\
\hline \multicolumn{5}{c}{ Sum } \\
\hline \multicolumn{5}{c}{ Mean } \\
\hline
\end{tabular}

The average data obtained from post-test students in the two sample classes is 69.29 in the experimental class and 42.71 in the control class. The results of the average data will be tested for the hypothesis using the t-test, prior to the calculation of the homogeneity and normality test of the data as a prerequisite for t-test analysis. the result of the t-test post test shows the sig value. (2-tailed) of $0.000<0.05$, it can be concluded that there is a significant difference between the post-test of the experimental class and the control class. So, from the results of the pretest and posttest of students in Kediri Regency, there was an increase in the ability of students to understand the characters that exist in the traditional. After being given the treatment, the provision of flashcards and the practice of the post-test scores showed a significant increase.

\subsection{Assistance in Makassar City}

Folk games and traditional sports in Makassar are Santo, Enggo-enggo, Macukke, Mabenteng, Mallongga, Lambasane, Maggale, Bu'uh Rawe, and Makkaddaro. 
Table 3. Pre-Test results for students in Makassar City

\begin{tabular}{clclc}
\hline \multirow{2}{*}{ No } & Experiment & & \multicolumn{2}{c}{ Control } \\
& Student's Name & Score & Student's Name & Score \\
\hline 1 & Student 1 & 8 & Student 1 & 16 \\
2 & Student 2 & 24 & Student 2 & 40 \\
3 & Student 3 & 36 & Student 3 & 30 \\
4 & Student 4 & 20 & Student 4 & 17 \\
5 & Student 5 & 32 & Student 5 & 20 \\
6 & Student 6 & 22 & Student 6 & 10 \\
7 & Student 7 & 32 & Student 7 & 25 \\
8 & Student 8 & 40 & Student 8 & 26 \\
9 & Student 9 & 48 & Student 9 & 15 \\
10 & Student 10 & 31 & Student 10 & 12 \\
11 & Student 11 & 23 & Student 11 & 20 \\
12 & Student 12 & 31 & Student 12 & 21 \\
13 & Student 13 & 20 & Student 13 & 12 \\
14 & Student 14 & Student 14 & 10 \\
\hline \multicolumn{2}{c}{ Total } & & & 274 \\
\hline
\end{tabular}

The average data obtained from the pre-test students in the two sample classes is 27.50 in the experimental class and 19.57 in the control class. The results of the average data will be tested using the t-test hypothesis. The results of the students' pre-t test can be seen the sig value. (2-tailed) of $0.034<0.05$, it can be concluded that there is a significant difference between the pre-test experimental class and the control class.

The average data obtained from post-test students in the two sample classes is 70.79 in the experimental class and 43.43 in the control class. The results of the average data will be tested for the hypothesis using the t-test, prior to the calculation of the homogeneity and normality test of the data as a prerequisite for t-test analysis. the results of the t-test post test showed the sig value. (2-tailed) of $0.000<0.05$, it can be concluded that there is a significant difference between the post-test of the experimental class and the control class. So, from the results of the pretest and posttest students in Makassar City, there was an increase in students' abilities in understanding the characters that exist in the traditional. After being given the treatment, the provision of flashcards and the practice of the post-test scores showed a significant increase.

Activities carried out when playing folk games and traditional games are proven to stimulate the emergence of affective aspects in students. the attitudes and values that appear during the activity tend to be purely from the will of the children.

This program presents a variety of problems that are instrumented in folk games and traditional sports. Students are asked to solve problems quickly and responsively. Communication skills, solidarity, praying for each other and not dropping, respecting each other both opponents or friends, and honesty that is so clearly visible. Even with folk games and traditional sports, a space for interaction between children is also opened very clearly and is not fake. 


\section{Conclusion}

The program for developing students in the context of global diversity through folk games and traditional sports provides inspiration and evidence that our children are basically born with good and noble character. Activities carried out when playing folk games and traditional games are proven to stimulate the emergence of affective aspects in students. the attitudes and values that appear during the activity tend to be purely from the will of the children. This program presents a variety of problems that are instrumented in folk games and traditional sports. Students are asked to solve problems quickly and responsively. Communication skills, solidarity, praying for each other and not dropping, respecting each other both opponents or friends, and honesty that is so clearly visible. Even with folk games and traditional sports, a space for interaction between children is also opened very clearly and is not fake. The hope is that this activity can be scheduled nationally and sustainably and become a routine. It does not need to be done on a festival scale which costs a fortune. But do it regularly and participate as a whole. (Just equate it like the skj gymnastics program on Friday morning). This activity is also useful as a means of recreation for students in their spare time when they are focused on undergoing full day school.

\section{References}

[1] J. Santrock, Educational psychology. New York: McGraw Hill, 2010.

[2] S. M. George, Dasar-Dasar Pendidikan Anak Usia Dini. Jakarta: Bumi Aksara, 2012.

[3] Y. Sujiono, Konsep Dasar Pendidikan Anak Usia Dini. Jakarta: Indeks, 2011.

[4] J. Gargiulo, R. \& Kilgo, Young children with special needs, in http://www.books.google.co.id/books, 2005.

[5] C. Dereau, Pembaru dan Kekuatan Lokal untuk Pembangunan, Aust. Community Dev. Civ. Soc. Strength. Scheme Phase II, 2013.

[6] Said, Moh. Pendidikan Karakter di Sekolah. Surabaya: Jaring Pena. 2013.

[7] Santrock, J. W. Educational psychology. 4th edition. New York: McGraw Hill. 2011

[8] Sulastri, Deteksi Perilaku Disruptif Anak (Studi Deskriptif Pada Taman Kanak-Kanak Gugus VI Singaraja). 2013. 